\title{
Factors Affecting Customers Loyalty to Mobile Services Companies' Brands
}

\author{
Mohamed Ali Barakat Ali ${ }^{1}$ \\ ${ }^{1}$ Business Administration Department, Faculty of Commerce, Ain Shams University, Cairo, Egypt \\ Correspondence: Mohamed Ali Barakat Ali, Assistant Professor of Business Administration, Faculty of \\ Commerce, Ain Shams University, Cairo, Egypt. E-mail: mabarakat35@yahoo.com
}

Received: March 22, $2020 \quad$ Accepted: April 23, $2020 \quad$ Online Published: April 27, 2020

doi:10.5539/ijms.v12n2p85 URL: https://doi.org/10.5539/ijms.v12n2p85

\begin{abstract}
The main aim of this study is building and testing a model that includes most factors that may affect and interpret customers' loyalty to mobile services companies' brands. Designed questionnaire was distributed to Egyptian mobile services companies' customers sample in stores of these companies. Data were obtained from 373 respondents and were analyzed using Amos.18 and Spss.16 to test hypotheses established in a research model. The results indicated that there is a positive significant relationship between brand awareness and brand associations. The results revealed that there is a positive significant relationship between brand associations and perceived brand quality. It is found that there is a positive significant relationship between brand associations, perceived brand quality and brand loyalty. It is found also that older customers are more loyal to the brand than younger customers. It is concluded that higher income customers are more loyal to the brand than lower income customers.
\end{abstract}

Keywords: brand associations, brand awareness, brand equity, brand loyalty, customers' demographics, perceived brand quality

\section{Introduction}

Since the concept "Brand Equity" has arisen in the 1980s, there has been an increasing interest in the subject among researchers and practitioners (Cobb-Walgren, Beal, \& Donthu, 1995). The Meaning of the concept brand equity has been debated in different ways (Keller, 2002). Although there is no agreed standard model for the brand equity till today, there are two main models that attract attention of most of scholars and managers. They are Aaker's model which was developed by David A. Aaker in 1991 and Keller model which was developed by Kevin L. Keller in 1993. Doyle (2001) mentioned that brands have been considered as the second most important assets for a firm after customers. Hamann, William and Omar (2007) mentioned that branding provides security to customers by assuring of the quality of products. Keller (1993) explained that positive brand equity can lead to greater revenues, lower costs, higher profits and greater firm's ability to command higher price.

\section{Research Problem}

To explore research problem pilot study was conducted. Marketing managers of mobile services companies were asked to determine the factors affecting brand loyalty. It was found that those managers cann't specify most factors affecting mobile services brand loyalty. This leads to the necessity of conducting this study. This study aims to identify most factors affecting customers loyalty to mobile services companies' brands and analyze the interrelationships among these factors. This study attempts to answer the following questions:

Q1: What are the determinants of customers loyalty to mobile services companies' brands? And what are directions of their effects?

Q2: What are the significance and direction of interrelationships among determinants of customers loyalty to mobile services companies' brands?

\section{Literature Review and Hypotheses Development}

\subsection{Brand Equity Concept and Its Dimensions}

Kotler (1991) defined a brand as a name, design or combination of them that is intended to identify the products of one seller or group of sellers and differentiate them from those of competitors. Aaker (1991) defined brand 
equity as a set of assets and liabilities linked to a brand's name and symbol that add to or subtract from the value provided by a product to a firm and its customers. Farquhar, Han and Ijiri (1991) defined brand equity as the added value provided by the brand name. Aaker (1992) mentioned that brand equity is the elements which affect the value of a brand. Keller (1993) mentioned that brand equity is the effect of brand awareness on customer response to marketing efforts of the brand. Simon and Sullivan (1993) defined brand equity as the value of a brand to the firm. Agarwal and Rao (1996) defined brand equity as overall quality and selection intention. Washburn and Plank (2002) defined brand equity as consumer awareness, familiarity and associations related to the brand. Bauer, Stockburger-Sauer and Exler (2008) mentioned that brand equity refers to the value of a specific brand in the mind of customers. Yoo, Donthu and Lee (2000) mentioned that brand equity is a multi-dimensional concept. Keller $(1993,2008)$ mentioned that brand equity as a multidimensional variable refers to the value inherent in a well-known brand name. Keller (2002) divided brand equity into two components: awareness and associations. Keller (2008) mentioned that customer-based brand equity occurs when the customer has a high level of awareness and familiarity with the brand and holds some strong and favorable brand associations in his/her memory. $\operatorname{Keller}(1993,2001,2008)$ mentioned that the value of a brand is created by marketers through self-identification with brand, superior quality, social esteem provided for users and customer trust in brand. Hoyer and Brown (1990), Dick and Basu (1994) mentioned that brand consists of some dimensions such as brand awareness, brand associations, perceived quality and brand loyalty. Keller (1996) grouped brand equity dimensions into five categories: brand awareness, brand associations, perceived quality, brand loyalty and other brand assets such as patents, trademarks and channels relationships. According to the previous discussion, the researcher concluded that the four dimensions of brand equity are brand awareness, brand associations, perceived brand quality and brand trust and brand loyalty can be considered as an outcome of brand equity.

\subsection{Brand Awareness and Brand Associations}

Aaker (1991, 1996) stated that brand awareness is one of the dimensions of brand equity. Yoo et al. (2000), Pappu and Quester (2006, 2008), Tong and Hawley (2009) empirically validated brand awareness as one of the dimensions of brand equity. Aaker (1996) defined brand awareness as strength of a brand's existence in the customer's memory. Rossiter and Percy (1987) defined brand awareness as the customer's ability to identify or recognize a brand. Keller (1993) mentioned that brand awareness can be measured by customer's ability to identify the brand under various circumstances and is considered more important in low involvement product categories. Aaker (1991) defined brand awareness as the ability of a consumer to recall that a brand is one part of a certain product category. Keller (1993) defined brand awareness as the consumer's recognition and recall capacity for a product. According to Keller (1993), brand awareness consists of two sub-dimensions: brand recognition and brand recall. Keller (1993) mentioned that brand recognition is the customer's ability to correctly identify a brand among others while brand recall represents the customer's ability to remember the name of the brand in a product category. Alba and Hutchinson (1987) indicated that brand awareness is a result of consumer exposure to a brand. Roy, Mukherjee and Bhattacharya (2018) found that knowledge as measure for brand awareness. Keller (2009) mentioned advertisement as a source of initial awareness and later associations for prices, designs and performance. Bornmark, Goransson and Svensson (2005) described that knowledge is derived from personal sources, commercial sources, public sources and experiential sources. Aaker (1991) and Keller (1993) defined brand associations as the information in the consumer's memory related to the brand. Aaker and Joachimsthaler (2000) defined brand associations whatever that customer relates to brand. It can include brand symbol, product design and characteristics and customer image making. Alba and Hutchinson (1987) categorized brand associations into three dimensions, they are attributes, benefits and attitudes. Attributes are features that typify the product. Benefits are personal value the consumer attaches to the product attributes. Attitudes are the consumers' complete evaluation of the brand based on the strength and favorability of the attributes and benefits associations. Keller $(1993,2003)$ concluded that customer-based brand equity depends on strength, favorability and uniqueness of brand associations; strength measures the intensity of connection between the associations and the brand; favorability means the desirability of the associations and uniqueness assesses specificity of the associations to the brand. Keller (1993) concluded that brand awareness affects positively the formation of strong and unique brand associations. Yoo et al. (2000), Kumar, Dash and Purwar (2013) suggested that brand awareness which is a lower degree of customer knowledge affects positively brand associations which is a higher degree of customer knowledge. Van Riel, De Mortanges and Streukens (2005) indicated that brand awareness is important for developing a strong and positive brand association. Low and Lamb (2000) stated that positive brand associations create positive attitudes toward brands. Aaker (1991) mentioned that brand associations are stronger when they are based on many exposures to communications. Yoo et al. (2000) reported that brand communication increases the incorporating the brand into customer's important 
set, shortens the process of brand purchasing and turning that selection into a habit. Based on the discussion above, the researcher suggests the following hypothesis:

H1-a: There is a positive significant relationship between brand awareness and brand associations.

\subsection{Brand Awareness and Perceived Brand Quality}

Nguyen, Baarett and Miller (2011) mentioned that perceived quality is based on the assessment of consumers about the attributes of a brand. Awareness is necessary to enable consumers to differentiate a brand's attributes from its competing brands. When consumers perceive that the brand has high quality compared to competitors' brands, they are likely to put a high value on the brand, driving their purchase and repurchase decisions. Aaker (1991), Yoo et al. (2000) mentioned that high brand awareness is a signal of quality that assists consumers in making purchase decision. Nguyen et al. (2011) concluded that brand awareness has a positive significant effect on perceived brand quality. Keller and Lehmann (2003), Pike, Bianchi, Kerr and Patti (2010), Stojanovic, Andreu and Curras-Perez (2018) confirmed that brand awareness affects significantly brand quality. Based on the discussion above, the researcher suggests the following hypothesis:

H1-b: There is a positive significant relationship between brand awareness and perceived brand quality.

\subsection{Brand Awareness and Brand Trust}

Yoon (2002), Mourad, Ennew and Kortam (2010) concluded that brand awareness affects significantly and positively brand trust. Das (2016) mentioned that the more awareness of a brand means more familiarity with the brand; this may reduce risk perceptions and thus enhances trust towards the brand. Based on the discussion above, the researcher suggests the following hypothesis:

H1-c: There is a positive significant relationship between brand awareness and brand trust.

\subsection{Brand Associations and Perceived Brand Quality}

Aaker $(1991,1996)$ stated that brand associations are one of the dimensions of brand equity. Yoo et al. (2000), Pappu and Quester (2006, 2008), Tong and Hawley (2009) empirically validated brand associations as one of the dimensions of customer-based brand equity. Aaker (1991) defined brand associations as anything related to a brand in customer's mind. Lassar, Mittal and Sharma (1995) defined brand associations as the relative strength of a consumer's positive feeling towards the brand. Emari, Jafari and Mogaddam (2012) mentioned that brand associations are what is in the consumer's memory about the brand either positive or negative. Keller (1993) mentioned that brand associations have three types, they are attributes, benefits and attitudes. Chen (2001) mentioned that brand associations can be seen in all forms and reflects features of the product or aspects independent of the product itself. Keller (1993) mentioned that in a product category crowded with similar competing brands, a brand needs to build unique image in order to distinguished from others. Keller (2003) pointed out that brand associations must be strong, unique and favorable to create brand equity. Aaker (1996) mentioned that brand associations help consumers to process, organize and retrieve information in memory and to create a reason to buy. Low and Lamb (2000) mentioned that consumers currently have so many alternative brands and they are very overloaded with information about them so, they tend to select from strong brands that have positive associations. Abimbola and Vallaster (2007) suggested that when the customers' experience of brand is positive, the brand becomes stronger and has a positive reputation. Asamoah (2014) mentioned that brands become competitive in the marketplace as a result of associations and behaviors of consumers towards them. Joubert and Poalses (2012) mentioned that marketers should create a distinctive brand image in customers' minds and customers depend on this image to make a choice. Aaker (1991) mentioned that brand associations help a firm in building strong competitive advantage and market position. Aaker (1991), Yoo and Donthu (2001) indicated that creating associations in customers' minds leads to customers' contact with the brand and perception of brand quality. Yoo et al. (2000) and Kumar et al. (2013) suggested that brand associations affect significantly the perception of quality. Bendixen, Bukasa and Abratt (2004) concluded that strong and positive associations affect customers' perceptions of a firm's service quality. Biedenbach (2012) concluded that there is hierarchical relationship between brand awareness, brand associations, perceived quality and brand loyalty. Based on the discussion above, the researcher suggests the following hypothesis:

H2: There is a positive significant relationship between brand associations and perceived brand quality.

\subsection{Perceived Brand Quality and Brand Trust}

Chiou and Droge (2006), Cho and Hu (2009), Alrubaiee and Alkaa'ida (2011) found that service quality positively affects trust. Lien, $\mathrm{Wu}, \mathrm{Chen}$ and Wang (2014) concluded that interaction quality and outcome quality positively affects customer's trust in a firm. Izogo, Ogba and Nwekpa (2016) found that service quality has a 
strong significant effect on trust. Based on the discussion above, the researcher suggests the following hypothesis:

H3: There is a positive significant relationship between perceived brand quality and brand trust.

\subsection{Brand Loyalty}

Shoell and Guiltinan (1990) defined brand loyalty as the degree to which a buyer concentrates his/her purchases overtime on a brand. Aaker (1991) defined brand loyalty as a situation which reflects how likely a customer will switch to another brand especially when that brand makes a change either in price or in product features. Aaker (1991) mentioned that brand loyalty is a significant source of competitive advantage because it builds up switching barriers which makes customers resistant to try new brands. Urde (1994) mentioned that brand loyalty is often indicated by the favorable attitude of consumers towards a brand and demonstrated by repeated purchase of the brand over time. Oliver (1997), Yoo and Donthu (2001) defined brand loyalty as intention to buy the brand as a primary choice. Oliver (1999) defined brand loyalty as a deep commitment to re buy a preferred brand in the future despite existence of marketing efforts that may cause switching behavior. Keller (2003) mentioned that brand loyalty refers to customer-brand relationship and the extent to which customers feel that they are "in sync" with the brand. Aaker (1991) considered brand loyalty a primary dimension of brand equity. In contrast, Keller (1993) viewed brand loyalty as a result of brand equity.

\subsection{Brand Associations and Brand Loyalty}

Ashill and Sinha (2004), Brakus, Schmitt and Zarantonello (2009), Kaynak, Salman, and Tatoglu (2008) indicated that brand associations can affect brand loyalty. Wu and Tian (2009) concluded that consumers' perceived associations significantly and positively affect consumers' loyalty toward the retailer. Joubert and Poalses (2012) mentioned that brands manufacturers should differentiate their brands from competitors' brands, establish positive brand associations and finally gain consumer loyalty. Qu, Kim and Im (2011), Kladou and kehagias (2014) indicated that brand loyalty is an outcome of brand image. Chang (2014) concluded that brand associations enhance consumers' brand loyalty. Kim, Choe and Petrick (2018) found that brand image has a positive significant impact on brand loyalty. Roy et al. (2018) indicated that brand associations are highly relevant in building satisfaction, preferences, loyalty and brand extension. Lee and Park (2019) found that brand associations have a positive influence on loyalty. Xu and Chen (2010) concluded that advertising and word of mouth which formulate customers' indirect experiences mainly create brand associations. Yoo et al. (2000) found that advertising spending reinforces brand associations, consequently brand loyalty will increase. Based on the discussion above, the researcher suggests the following hypothesis:

H4-a: There is a positive significant relationship between brand associations and brand loyalty.

\subsection{Perceived Brand Quality and Brand Loyalty}

Aaker $(1991,1996)$ stated that perceived quality of brand is one of the dimensions of brand equity. Yoo et al. (2000), Pappu and Quester (2006, 2008), Tong and Hawley (2009) empirically validated perceived brand quality as one of the dimensions of brand equity. Aaker (1996) stated that a central aspect of brand equity framework is the quality dimension. Zeithmal (1988) defined perceived quality as customer's perception of the overall quality or superiority of the product or service with respect to its intended purpose relative to alternatives. Asamoah (2014) defined perceived quality as the assessment of the superiority of the brand compared to other similar substitutes, in other word, the ability of a brand to offer the necessary level of satisfaction better than other alternatives. Rust and Oliver (1994) view that overall perceived service quality is based on a customer's evaluation of three dimensions of the service encounter: Outcome Quality which was called as technical quality (Gronroos, 1984), Customer-Employee Interaction Quality which was called functional quality (Gronroos, 1984) and Environment Quality (Bitner, 1992). Asamoah (2014) mentioned that when the firm creates a brand it should match the attributes of the brand to the needs and expectations of the consumers. Yoo et al. (2000) stated that consumers generally perceive highly advertised brands as higher quality brands. Anselmsson, Tohansson and Persson (2007) mentioned that brand equity implies that the brand should be well known for something that is valuable to the consumer. Aaker (1991) mentioned that perceived quality lends value to a brand in several ways: high quality gives consumers a good reason to buy the brand, allows the brand to differentiate itself from its competitors, to attracts the attention of distribution channels, to charge a premium price and to have a strong basis for brand extension. Urde (1994) emphasized that having a high-quality brand enables the company that owns the brand to become attractive and competitive in the market. Bolton and Drew (1991) suggested that service quality has significant effects on customer loyalty. Bloemer, Buyter and Wetzels (1997), Jones, Beatty and Mothersbaugh (2002) pointed out that there is a positive relationship between perceived service quality and repurchase intention, recommendation and resistance to better alternatives. Wu and Tian (2009) concluded that 
quality of a retailer positively influences consumers' loyalty toward the retailer. Yang and Peterson (2004) indicated that as consumers perceive that a retailer improves its quality in general, they will be more committed to the retailer. Nguyen et al. (2011) concluded that there is a positive significant relationship between perceived brand quality and brand loyalty. Qu et al. (2011), Kaldou and Kehagias (2014) indicated that brand loyalty is an outcome of perceived brand quality. Chang (2014) concluded that perceived brand quality reinforces customers' brand loyalty. Dib and Alhaddad (2014) concluded that perceived quality affects positively brand loyalty. Kim et al. (2018) found that there is a positive significant relationship between perceived brand quality and brand loyalty. Based on the discussion above, the researcher suggests the following hypothesis:

H4-b: There is a positive significant relationship between perceived brand quality and brand loyalty.

\subsection{Brand Trust and Brand Loyalty}

Doney and Cannon (1997) defined brand trust as confident expectations of the brand's perceived credibility and benevolence in situations entailing risk to the customer. Anderson and Narus (1990) defined trust as buyer's belief that the service provider and its employees will perform actions that will result in positive outcomes and not engage in unexpected behavior with negative outcomes. Moorman et al. (1992) defined trust as willingness to rely on a confident exchange partner. Morgan and Hunt (1994) defined trust as extent of confidence in the exchange of partner's reliability and integrity. Sirdeshmukh, Singh and Sabol (2002) defined trust as the customer's expectations that the service provider can be relied on to get the promised service. Blankston (1992), Lassar et al. (1995), Doney and Cannon (1997), Chaudhuri and Holbrook (2001), Rios and Riquelme (2008), Burmann, Jost-Benz and Riley (2009) theorized brand trust as a dimension of brand equity. Parasuraman et al. (1985) examined the role of trust as a critical success factor in successful service relationships. Berry (1995) suggested that relationship marketing is built on the foundation of trust. $\mathrm{Wu}$, Chen and Chung (2010) argued that trust relationship is the key to a successful marketing relationship. Hoffman, Novak and Peralta (1999) mentioned that trusted brands are to be purchased more frequently and a long-term brand-customer relationship is made. Gefen (2000) observed that trust can reduce perceived risk, uncertainty and complexity of transactions. Chaudhuri and Holbrook (2001), Harris and Goode (2004), Gounaris (2005) suggested that trust is a significant determinant of customer loyalty. Sirdeshmukh et al. (2002) directly linked trust to loyalty. Alhabeeb (2007) mentioned that consumers naturally seek utility maximization and firms submit that contributing to the creation of a positive net value for consumers would establish consumer trust which leads to a state of brand loyalty. Dib and Alhaddad (2014) concluded that brand trust has a positive effect on brand loyalty. Izogo et al. (2016) found that trust affect strongly and positively commitment. Based on the discussion above, the researcher suggests the following hypothesis:

H4-c: There is a positive significant relationship between brand trust and brand loyalty.

\subsection{Brand Awareness and Brand Loyalty}

Hoyer and Brown (1990) mentioned that consumers are more likely to choose a brand that they are aware of even if the quality of the brand's product is lower than others. Baldauf, Gravens, and Binder (2003) mentioned that the most favored brands are those that are easily recognizable or identifiable, categorized and eventually purchased. Asamoah (2014) mentioned that the brands that customers are familiar with are usually taken into consideration in the pecking order. Atilgan, Aksoy and Akinci (2005) mentioned that brand awareness offers consumers three main advantages: learning advantages, consideration advantages and choice advantages. Aaker (1991) mentioned that loyalty begins with the customer's becoming aware of the product. Keller (1993) mentioned that high levels of brand awareness and positive brand image should increase the probability of brand choice as well as produce greater customer loyalty and decrease vulnerability to competitive marketing actions. Ashill and Sinha (2004), Brakus et al. (2009), Kaynak et al. (2008) indicated that brand awareness can affect brand loyalty. $\mathrm{Wu}$ and Tian (2009) concluded that consumers' perceived awareness affects significantly and positively consumers' loyalty toward the retailer. Qu et al. (2011), Kaldou and Kehagias (2014) indicated that brand loyalty is an outcome of brand awareness. Chang (2014) concluded that brand awareness enhances consumers' brand loyalty. Kim et al. (2018) found that there is a positive significant relationship between brand awareness and brand loyalty. Su and Chang (2018) concluded that brand awareness has a significant and positive impact on brand loyalty. Based on the discussions above, the researcher suggests the following hypotheses:

H5: There is a positive significant relationship between brand awareness and brand loyalty.

H6-a: Brand associations mediate the relationship between brand awareness and brand loyalty.

H6-b: Perceived brand quality mediates the relationship between brand awareness and brand loyalty.

H6-c: Brand trust mediates the relationship between brand awareness and brand loyalty. 


\subsection{Customers' Demographics and Brand Loyalty}

East, Harris, William and Lomax (1995) mentioned that demographic characteristics influence store loyalty. Anic and Radas (2006) concluded that female consumers were more loyal to store than male consumers. Raut (2015) concluded that the female customers show stronger brand loyalty than the male customers. Saad, Ishak and Johari (2013) mentioned that women make decisions based on social values, they take into consideration the impact of these decisions on others, so, they prefer to feel over thinking and making decisions on objective, impersonal and logical consideration. Anic and Radas (2006) concluded that older shopper groups are higher loyal than younger shopper groups. Patterson (2007) concluded that older age groups exhibit significant and more loyal behavior than younger age groups. Moisescu (2009) mentioned that age can influence repurchase intentions significantly. Afzal and Pakistan (2013) concluded that there is a positive impact of age on customer loyalty. Raut (2015) concluded that there is significant difference in the level of brand loyalty among customers according to their age. Wood (2004) mentioned that older consumers are more conservative and less willing to try new brands. Raut (2015) concluded that there is significant difference in the level of brand loyalty among customers according to their income. Hai and Seetharaman (2009) suggested that there is a positive relationship between income and brand loyalty. Hai and Seetharaman (2009) argue that higher income consumers are more brand loyal than lower income consumers. Saad et al. (2013) pointed out that income level has a positive relationship with customer loyalty. Peterson (1995) described that consumers enter into a marketing relationship only because they expect to receive some values, monetary value is one of these values. Mishra and Prasad (2014) concluded that there is a negative relationship between income and brand loyalty. Mishra and Prasad (2014) concluded that the lower the income levels, the higher the loyalty of consumers to a brand and vice versa. East et al. (1995) indicated that high income shoppers who concerned about prices are less loyal. Moisescu (2009) mentioned that education can influence repurchase intentions significantly. Afzal and Pakistan (2013) concluded that there is a positive impact of academic qualification on customer loyalty. Mishra and Prasad (2014) concluded that there is a positive relationship between education and brand loyalty. Mishra and Prasad (2014) mentioned that the higher the level of education, the greater the loyalty of consumers to a brand and vice versa. Mishra and Prasad (2014) mentioned that when consumers make an informed choice of a product brand, they tend to stick to their decision through a period resulting in repeated purchases as they are sure of their choice. Based on the above discussion, the researcher suggests the following hypotheses:

H7-a: Female customers are more loyal to the brand than male customers.

H7-b: Older customers are more loyal to the brand than younger customers.

H7-c: Higher income customers are more loyal to the brand than lower income customers.

H7-d: Higher educated customers are more loyal to the brand than lower educated customers.

\section{Proposed Model}

Figure 1 illustrates the proposed model of the study. It includes the hypothesized relationships. The factors under investigation are brand awareness, brand associations, perceived brand quality, brand trust, customers' demographics and brand loyalty. Accordingly, the researcher aims to examine the mentioned relationships on mobile services companies' brands in developing context namely Egypt. 


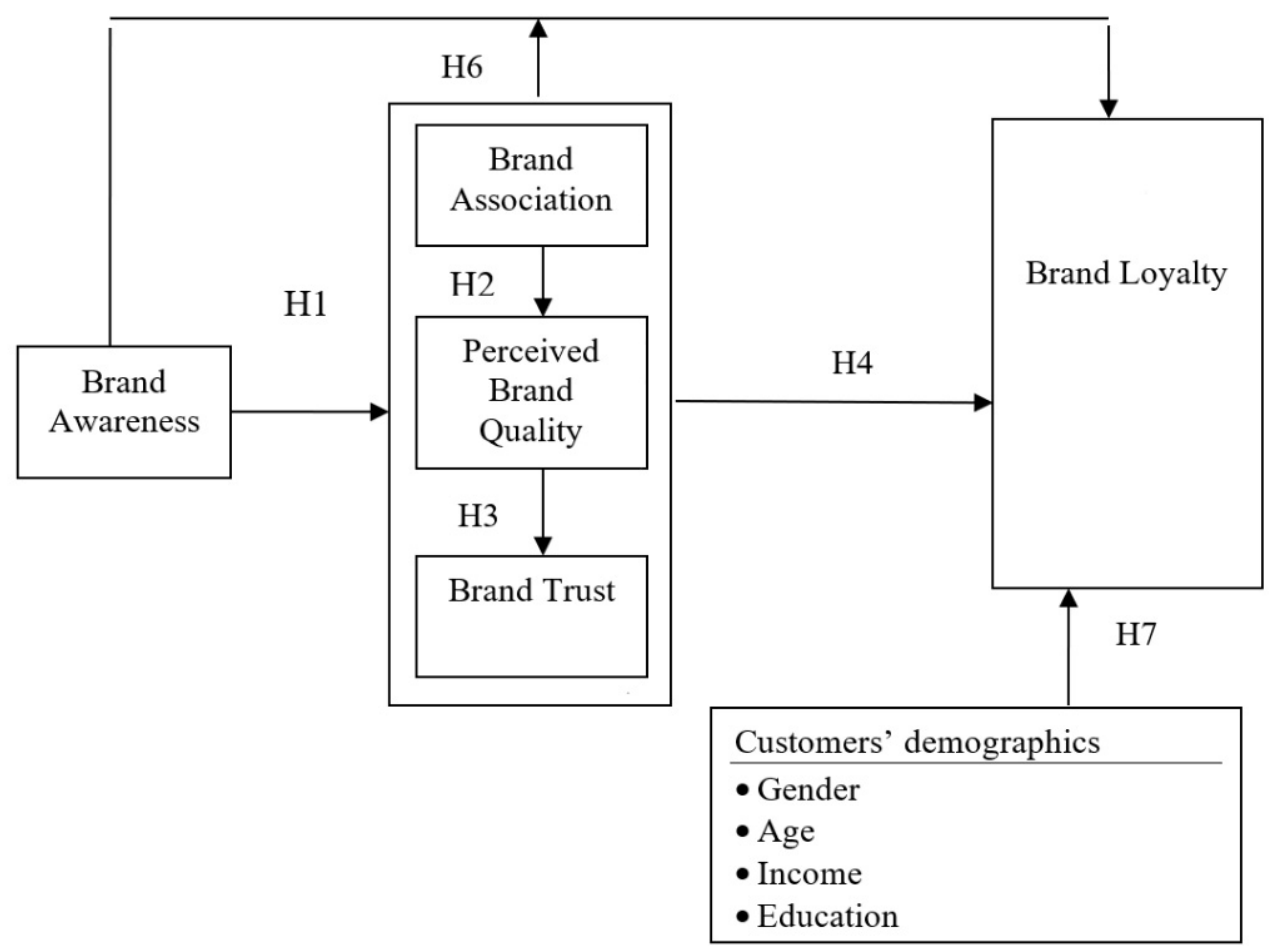

Figure 1. Proposed model

\section{Methodology}

\subsection{Sample and Data Collection}

Data were collected from customers of mobile service companies through distributing designed questionnaire to those customers who are visitors of mobile service companies' stores. Sample size was 450 customers of mobile service companies in Egypt. Sample size was calculated by sample size calculator according to the following assumptions: population size $=96,007,000$ customers, confidence level $=95 \%$, allowed margin error $= \pm 5 \%$ and level of accuracy $=50 \%$. Sample size calculated $=384$ customers. Sample size was increased to 450 customers to decrease standard error and increase responsiveness rate. The distribution of research population and sample is represented in Table 1. The demographic characteristics of respondents are shown in Table 2.

Table 1. Distribution of research population and sample

\begin{tabular}{lllll}
\hline Company & Population Size & Percentage & Sample Size & Respondents \\
\hline Vodafone & $41,743,000$ & $43.5 \%$ & 195 & 145 \\
Orange & $31,168,000$ & $32.5 \%$ & 147 & 138 \\
Etisalat & $19,796,000$ & $20.6 \%$ & 93 & 78 \\
We & $3,300,000$ & $3.4 \%$ & 15 & 12 \\
Total & $96,007,000$ & $100 \%$ & 450 & 373 \\
\hline
\end{tabular}


Table 2. Demographics of respondents

\begin{tabular}{llll}
\hline Demographics & Categories & Number & Percentage \\
\hline Gender & Male & 187 & $50.1 \%$ \\
Age & Female & 186 & $49.9 \%$ \\
& Less than 18 & 12 & $3.2 \%$ \\
& $18-$ less than 30 & 134 & $35.9 \%$ \\
& 30-less than 40 & 119 & $31.9 \%$ \\
& 40-less than 50 & 82 & $22 \%$ \\
Income & 50-less than 60 & 16 & $4.3 \%$ \\
& 60 or more & 10 & $2.7 \%$ \\
& Less than 1000 & 45 & $12.1 \%$ \\
& $1000-$ less than 3000 & 141 & $37.8 \%$ \\
& 3000-less than 6000 & 113 & $30.3 \%$ \\
Education & 6000-less than 10000 & 63 & $16.9 \%$ \\
& $10000-$ less than 15000 & 9 & $2.4 \%$ \\
& 15000 or more & 2 & $0.5 \%$ \\
& Pre-Secondary Education & 15 & $4 \%$ \\
& Secondary Education & 91 & $24.4 \%$ \\
& High Education & 179 & $48 \%$ \\
& Diploma & 24 & $6.4 \%$ \\
& Master & 52 & $14 \%$ \\
& PHD & 12 & $3.2 \%$ \\
\hline
\end{tabular}

\subsection{Research Measures}

The measures used in this study are represented in Table 3. The measures' items are presented in Appendix A. Table 4 shows that all constructs exhibited acceptable composite reliability values exceeding the minimum limit 0.7 suggested by Bagozzi (1994).

Table 3. Research measures

\begin{tabular}{lll}
\hline Construct & Measures & Number of Items \\
\hline Brand Awareness (BAW) & Yoo et al., 2000 & 3 \\
Brand Association (BAS) (strength and & Yoo et al., 2000 & 2 \\
favorability) & Tong and Hawley, 2009 & 1 \\
& Aaker, 1996 & 1 \\
Brand Perceived Quality (PBQ) & Aaker, 1996 & 6 \\
& Daggar et al., 2007 & 4 \\
Brand Trust (BT) & Doney and Cannon, 1997 & 5 \\
Brand Loyalty (BL) & Yoo et al., 2000 & 8 \\
\hline
\end{tabular}

Table 4. Reliability test

\begin{tabular}{lll}
\hline Construct & Number of Items & Composite reliability \\
\hline Brand Awareness & 2 & 0.829 \\
Brand Association & 3 & 0.840 \\
Brand Perceived Quality & 10 & 0.926 \\
Brand Trust & 5 & 0.904 \\
Brand Loyalty & 8 & 0.909 \\
\hline
\end{tabular}

To test the construct validity of scales used in the study, both exploratory and confirmatory factor analyses were used. Exploratory factor analysis using principle component analysis extraction method and varimax rotation method was employed on the 28 -item scale developed for measuring brand equity dimensions in this study. The Bartlett test of sephericity was significant $\left(\chi^{2}=8283.222, p=0.000\right)$ and the Kaiser-Meyer-Olkin measure of sampling adequacy $(\mathrm{KMO}=0.940)$ was greater than 0.5 which show that the use of factor analysis was appropriate. 28 items in the questionnaire were reduced to five factors. Factor loading for each scale item maintained the minimum standard of 0.5. These results are shown in Table 5. The resultant factor structure explained $69.53 \%$ of high communalities across the scale components. Eigen values for all five factors were 
greater than 1 (brand awareness $=2.232$; brand associations $=5.705$, perceived brand quality $=4.030$; brand trust $=3.734$; brand loyalty $=3.766$ ).

Table 5. Exploratory factor analysis for brand equity variables

\begin{tabular}{|c|c|c|c|c|c|}
\hline \multirow[t]{2}{*}{ Variable } & \multicolumn{5}{|c|}{ Component } \\
\hline & 1 & 2 & 3 & 4 & 5 \\
\hline BAW2 & & & & & 0.840 \\
\hline BAW3 & & & & & 0.884 \\
\hline BAS1 & 0.532 & & & & \\
\hline BAS2 & 0.518 & & & & \\
\hline BAS3 & 0.546 & & & & \\
\hline PBQ1 & & 0.687 & & & \\
\hline PBQ2 & & 0.706 & & & \\
\hline PBQ3 & & 0.656 & & & \\
\hline PBQ4 & & 0.576 & & & \\
\hline PBQ5 & & 0.551 & & & \\
\hline PBQ6 & & 0.662 & & & \\
\hline PBQ7 & & 0.561 & & & \\
\hline PBQ8 & & 0.698 & & & \\
\hline PBQ9 & & 0.783 & & & \\
\hline PBQ10 & & 0.792 & & & \\
\hline BT1 & & & & 0.560 & \\
\hline BT2 & & & & 0.672 & \\
\hline BT3 & & & & 0.801 & \\
\hline BT4 & & & & 0.705 & \\
\hline BT5 & & & & 0.684 & \\
\hline BL1 & & & 0.515 & & \\
\hline BL2 & & & 0.644 & & \\
\hline BL3 & & & 0.530 & & \\
\hline BL4 & & & 0.783 & & \\
\hline BL5 & & & 0.800 & & \\
\hline BL6 & & & 0.767 & & \\
\hline BL7 & & & 0.565 & & \\
\hline BL8 & & & 0.489 & & \\
\hline
\end{tabular}

To test the construct validity of measures of research a confirmatory factor was computed also. Fit indices of the CFA model for brand equity are as follows: $\chi 2 / \mathrm{DF}=212.581 / 55=3.865, \mathrm{P}=0.000, \mathrm{RMR}=0.053, \mathrm{GFI}=0.921$, $\mathrm{AGFI}=0.869, \mathrm{NFI}=0.936, \mathrm{RFI}=0.910, \mathrm{IFI}=0.952, \mathrm{TLI}=0.931, \mathrm{CFI}=0.952, \mathrm{RMSEA}=0.088 . \chi 2 / \mathrm{DF} \leq 3$, RMR and RMSEA $\leq 0.08$ and GFI, AGFI, NFI, RFI, IFI, TLI and CFI $\geq 0.90$. Fit values are well within acceptable range. These values indicated that there is a good fit between structural model and data (Bryne, 2010). All correlations are significant at 0.001 . This result is presented in Table 6. Figure 2 illustrates the CFA model for measuring brand equity.

Table 6. Confirmatory factor analysis for brand equity variables

\begin{tabular}{llllll}
\hline Path & $\begin{array}{l}\text { Standardized Regression } \\
\text { Weights }\end{array}$ & $\begin{array}{l}\text { Un Standardized Regression } \\
\text { Weights }\end{array}$ & $\begin{array}{l}\text { Standard } \\
\text { Error }\end{array}$ & $\begin{array}{l}\text { Critical } \\
\text { Ratio }\end{array}$ & Probability \\
\hline F1 $\rightarrow$ BAW3 & 0.977 & 1.000 & - & - & - \\
F1 $\rightarrow$ BAW2 & 0.726 & 0.692 & 0.071 & 9.752 & $* * *$ \\
F2 $\rightarrow$ BAS3 & 0.844 & 1.000 & - & - & - \\
F2 $\rightarrow$ BAS1 & 0.818 & 0.989 & 0.057 & 17.454 & $* * *$ \\
F3 $\rightarrow$ PBQ10 & 0.884 & 1.000 & - & - & - \\
F3 $\rightarrow$ PBQ9 & 0.852 & 0.917 & 0.042 & 22.037 & $* * *$ \\
F3 $\rightarrow$ PBQ8 & 0.892 & 0.974 & 0.041 & 23.981 & $* * *$ \\
F4 $\rightarrow$ BT5 & 0.925 & 1.000 & - & - & - \\
F4 $\rightarrow$ BT4 & 0.838 & 0.837 & 0.041 & 20.367 & $* * *$ \\
F5 $\rightarrow$ BL8 & 0.793 & 1.000 & - & - & - \\
F5 $\rightarrow$ BL7 & 0.818 & 0.772 & 0.046 & 16.645 & $* * *$ \\
F5 $\rightarrow$ BL6 & 0.737 & 0.731 & 0.050 & 14.726 & $* * *$ \\
F5 $\rightarrow$ BL1 & 0.708 & 0.831 & 0.059 & 14.048 & $* * *$ \\
\hline
\end{tabular}




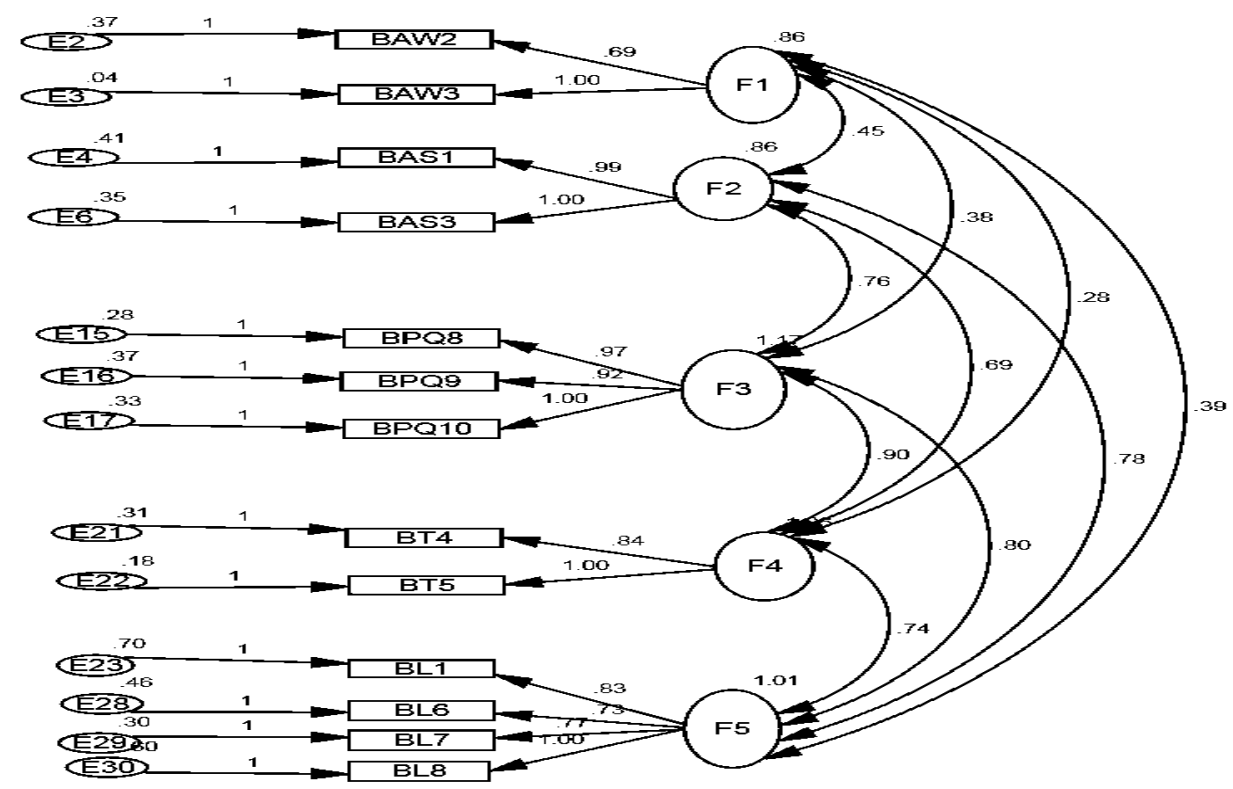

Figure 2. CFA model for measuring brand equity

Table 7 shows that AVE (average variance extracted) for all constructs were greater than 0.5 confirming internal consistency and convergent validity (Fornell \& Larcker, 1981).

Table 7. Convergent validity

\begin{tabular}{ll}
\hline Variable & Average Variance Extracted (AVE) \\
\hline Brand Awareness & 0.855 \\
Brand Association & 0.758 \\
Brand Perceived Quality & 0.604 \\
Brand Trust & 0.723 \\
Brand Loyalty & 0.619 \\
\hline
\end{tabular}

Table 8 shows that the square root of AVE for each construct was greater than the absolute value of the correlation of each pair of constructs confirming discriminant validity.

Table 8 . The discriminant validity

\begin{tabular}{lllllll}
\hline Construct & Square Root Of AVE & BAW & BAS & PBQ & BT & BL \\
\hline BAW & 0.925 & 1 & & & & \\
BAS & 0.870 & $0.437^{* *}$ & 1 & & & \\
PBQ & 0.777 & $0.350^{* *}$ & $0.650^{* *}$ & 1 & & \\
BT & 0.850 & $0.292^{* *}$ & $0.624^{* *}$ & $0.721^{* *}$ & 1 & \\
BL & 0.787 & $0.385^{* *}$ & $0.695^{* *}$ & $0.660^{* *}$ & $0.648^{* *}$ & 1 \\
\hline
\end{tabular}

Note. $* *$ Correlation is significant at the 0.01 level.

Table 9 shows the test of normality of all constructs items which were checked using skewness and kurtosis tests. The results show that all values fall within the acceptable range from -1 to +1 supporting the normality (Bagozzi \& Yi, 1988). 
Table 9. Normality test

\begin{tabular}{llllll}
\hline Construct & Items & Mean & Standard Deviation & Skweness & Kurtosis \\
\hline BAW & BAW2 & 4.193 & 0.886 & -1.203 & 1.492 \\
& BAW3 & 4.172 & 0.952 & -1.459 & 2.233 \\
BAS & BAS 1 & 3.858 & 1.121 & -0.938 & 0.000 \\
& BAS 3 & 3.796 & 1.098 & -0.789 & -0.250 \\
PBQ & PBQ 8 & 3.520 & 1.184 & -0.655 & -0.624 \\
& PBQ 9 & 3.491 & 1.168 & -0.441 & -0.849 \\
& PBQ 10 & 3.558 & 1.227 & -0.494 & -0.898 \\
BT & BT 4 & 3.536 & 1.028 & -0.696 & -0.273 \\
& BT 5 & 3.442 & 1.112 & -0.585 & -0.578 \\
BL & BL 1 & 3.547 & 1.183 & -0.701 & -0.424 \\
& BL 6 & 3.780 & 0.999 & -0.991 & 0.634 \\
& BL 7 & 3.936 & 0.951 & -1.228 & 1.588 \\
& BL 8 & 3.606 & 1.271 & -0.720 & -0.581 \\
\hline
\end{tabular}

\section{Results}

The proposed hypotheses in the proposed model (H1-H8) were tested by using structural equation modeling technique (SEM) through path analysis. Table 10 shows the results of bath analysis for the research model.

Table 10. Bath analysis

\begin{tabular}{llllll}
\hline Significant Structural Paths & Standard Loadings & Un standard Loadings & S.E. & C.R. & P \\
\hline BAW $\rightarrow$ BAS & 0.437 & 0.525 & 0.056 & 9.379 & $* * *$ \\
BAS $\rightarrow$ PBQ & 0.650 & 0.698 & 0.042 & 16.489 & $* * *$ \\
BAS $\rightarrow$ BL & 0.460 & 0.411 & 0.040 & 10.149 & $* * *$ \\
$\mathrm{PBQ} \rightarrow \mathrm{BL}$ & 0.300 & 0.300 & 0.038 & 7.971 & $* * *$ \\
\hline
\end{tabular}

Fit indices of bath analysis for the research model are as follows: $\chi 2 / \mathrm{DF}=(6.949 / 2=3.474), \mathrm{P}=0.031, \mathrm{RMR}=$ $0.028, \mathrm{GFI}=0.991, \mathrm{AGFI}=0.954, \mathrm{NFI}=0.988, \mathrm{RFI}=0.965, \mathrm{IFI}=0.992, \mathrm{TLI}=0.975, \mathrm{CFI}=0.992, \mathrm{RMSEA}=$ 0.082 . Fit values are well within acceptable range. These values indicated that there is a good fit between structural model and data. Figure 3 shows the tested model.

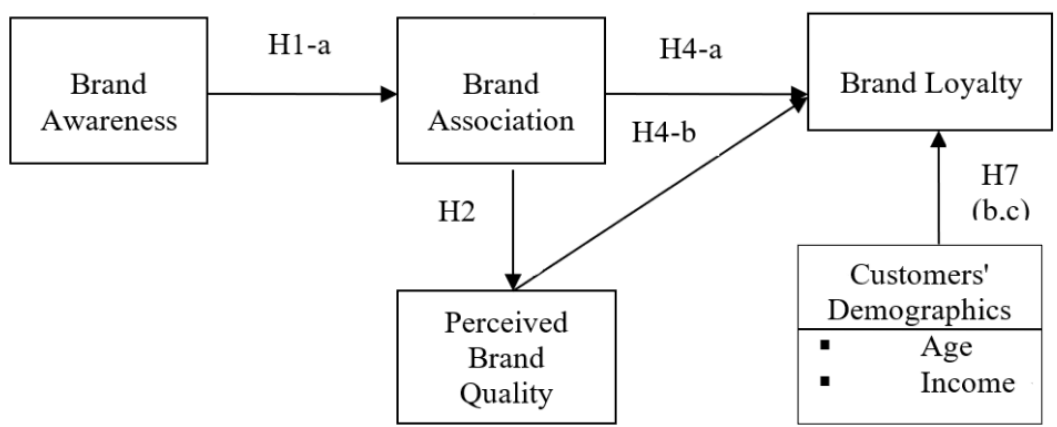

Figure 3. Tested model

According to the results of bath analysis it was found that there is a positive significant relationship between brand awareness and brand associations so, H1-a was supported. This result coincides with results of previous studies. It was concluded that there is no significant relationship between brand awareness and perceived brand quality so, H1-b was rejected. This result differs from results of previous studies. Results indicated that there is no significant relationship between brand awareness and brand trust so, H1-c was rejected. This result differs from results of previous studies. It was found that there is a positive significant relationship between brand associations and perceived brand quality so, $\mathrm{H} 2$ was supported. This result coincides with results of previous studies. Results revealed that there no significant relationship between perceived brand quality and brand trust so, H3 was rejected. This result differs from results of previous studies. Results indicated that there is a positive 
significant relationship between brand associations and brand loyalty so, H4-a was supported. This result coincides with results of previous studies. It was concluded that there is a positive significant relationship between perceived brand quality and brand loyalty so, H4-b was supported. This result coincides with results of previous studies. Results indicated that there is no significant relationship between brand trust and brand loyalty so, H4-c was rejected. This result differs from results of previous studies. It is found that there is no significant relationship between brand awareness and brand loyalty so, H5 was rejected. It was included that brand associations mediate the relationship between brand awareness and brand loyalty so, H6-a was supported. This result is shown in Table 11.

Table 11. Moderating effects

\begin{tabular}{llll}
\hline Path & Standardized direct effect & Standardized indirect effect & Standardized total effect \\
\hline $\mathrm{BAW} \rightarrow \mathrm{BAS} \rightarrow \mathrm{BL}$ & 0.000 & 0.304 & 0.304 \\
\hline
\end{tabular}

It was concluded that a perceived brand quality doesn't mediate the relationship between brand awareness and brand loyalty so, H6-b was rejected. It was found that brand trust doesn't mediate the relationship between brand awareness and brand loyalty so, H6-c was rejected. The equality of means of brand loyalty for both women and men was tested, it is found that the mean of brand loyalty for women equals (3.72) and the mean of brand loyalty for men equals (3.71) and the mean difference was not significant. So, $\mathrm{H} 7$-a was rejected. This result differs from results in previous studies. The significance of differences in levels of brand loyalty among customers according to their age was tested using ANOVA and LSD test, it is found that the differences in levels of brand loyalty among customers according to their age are significant $(F=9.283, p<0.05)$. The mean of brand loyalty of customers whose age is from 50 years to less than 60 years equals (4.156), the mean of brand loyalty of customers whose age is from 18 years to less than 30 years equals (3.334) and the mean difference is significant at 0.05 level $(\mathrm{p}<0.05)$. Hence, older customers are more loyal to the brand than younger customers because older customers are more conservative and less willing to try new brands. So, H7-b was supported. This result coincides with results of previous studies. The significance of differences in levels of brand loyalty among customers according to their income was tested using ANOVA and LSD test, it is found that the differences in levels of brand loyalty among customers according to their income are significant $(\mathrm{F}=11.902, \mathrm{p}<0.05)$. The mean of brand loyalty of customers whose income is from L.E 6000 to less than L.E 10000 equals (4.254). The mean of brand loyalty of customers whose income is less than L.E 1000 equals (3.439) and the mean difference is significant at 0.05 level $(\mathrm{p}<0.05)$. Hence, higher income customers are more loyal to the brand than lower income customers because higher income customers are more concerned about high service quality and less concerned about low service price so, if the perceived service quality is high, the higher income customers will be loyal to the brand. So, H7-c was supported. This result coincides with results of previous studies. The significance of differences in levels of brand loyalty among customers according to their education level was tested using ANOVA and LSD test, it is found that the differences in levels of brand loyalty among customers according to their education level are not significant $(\mathrm{F}=0.679, \mathrm{P}>0.05)$. So, H7-d was rejected. This result differs from results in previous studies.

\section{Discussion and Conclusions}

Building customer's brand awareness can be occurred through informing the customer with characteristics and advantages of the mobile service brand. The customer can be aware of characteristics and advantages of mobile service brand through company's advertisements and customer's visiting of company's website on the internet. Gathered information from mobile service company's advertisements and website and customer's personal experiment of mobile service build customer's brand awareness. Customer's brand awareness forms customer's brand associations. Positive mobile service brand associations lead to high perceived mobile service quality. Both positive customer's service brand associations and high customer's perceived service quality increase customer's mobile service brand loyalty. There are significant differences in levels of brand loyalty among customers according to their age and income. Older customers are more loyal to the brand than younger customers. Higher income customers are more loyal to the brand than lower income customers. The differences in levels of brand loyalty among customers according to their gender and education are not significant.

\section{Managerial Implications}

According to the results of the current study, mobile services company should attract new customers and maintain current customers and gain possible maximum market share. The mobile services company should make attractive and informative advertisements that get the customer to be aware and familiar with the brand of 
the company. The mobile services company should differentiate the services and prices of the company from those of competitors through its offers and advertisements in order to build strong, favorable and unique brand associations in customer memory. The mobile services company should invite the customers to visit the company's website to be aware of all services, prices and branches of the company. The mobile services company should provide all services that the customer may need such as local calls, messaging, international calls, roaming, missed call keeper, unwanted caller and voice mail. The mobile services company should provide the customers with high quality service, keep its promises to its customers and achieve the reliability and integrity of transactions between company and customers. The mobile services company should use three main tools of building brand loyalty, brand awareness, brand associations, and perceived brand quality. The mobile services company should give much attention to all customers especially who are young and low income because they are often less loyal to mobile service company brand. Managers of mobile services companies should reinforce their customers' loyalty toward their brands through informing the customers about the characteristics and advantages of the brand, establishing positive ideas about the brand in customers' minds and raising the perceived brand quality.

\section{Limitations and Future Research}

The current study explained how customer brand loyalty can be formed in mobile service industry. There is a need to implement other researches to explain how customer brand loyalty can be formed in other industries.

\section{References}

Aaker, D. A. (1991). Managing Brand Equity. New Jersey, NY: The Free Press.

Aaker, D. A. (1992). The Value of Brand Equity. Journal of Business Strategy, 13(4), 27-32. https://doi.org/10.1108/eb039503

Aaker, D. A. (1996a). Building Strong Brands. New Jersey, NY: The Free Press.

Aaker, D. A. (1996b). Measuring Brand Equity Across Products and Markets. California Management Review, 38(3), 102-120. https://doi.org/10.2307/41165845

Aaker, D. A., \& Joachimsthaler, E. (2000). Brand Leadership, Building Assets in the Information Society. New York, NY: Free Press.

Abimbola, T., \& Vallaster, C. (2007). Brand, Organizational Identity and Reputation in SMEs: An Overview. Qualitative Market Research: An International Journal, 10 (4), 341-348. https://doi.org/10.1108/13522750710819685

Afzal, N., \& Pakistan, S. (2013). Impact of Customer Satisfaction and Demographic Factors on Customer's Loyalty in Banking Sector of Pakistan. Journal of Scientific Research, 18(5), 721-727.

Agarwal, M. K., \& Rao, V. (1996). An Empirical Comparison of Consumer Based Measures of Brand Equity. Marketing Letters, 7(3), 237-247. https://doi.org/10.1007/BF00435740

Al-Habeeb, M. J. (2007). On Consumer Trust and Product Loyalty. International Journal of Consumer Studies, 31, 609-612. https://doi.org/10.1111/j.1470-6431.2007.00622.x

Alba, J. W., \& Hutchinson, J. W. (1987). Dimensions of Consumer Expertise. Journal of Consumer Research, 13(4), 411-454. https://doi.org/10.1086/209080

Alrubaiee, L., \& Alkaa'ida, F. (2011). The Mediating Effect of Patient Satisfaction in the Patients' Perceptions of Healthcare Quality-Patient Trust Relationship. International Journal of Marketing Studies, 3(1), 103-127. https://doi.org/10.5539/ijms.v3n1p103

Anderson, J. C., \& Narus, J. A. (1990). A Model of Distributor Firm and Manufacturer Firm Working Partnerships. Journal of Marketing, 54, 42-58. https://doi.org/10.1177/002224299005400103

Anic, I., \& Radas, S. (2006). The Role of Satisfaction and Demographic Factors in Building Store Loyalty: Hypermarket Case Study in Croatia. Privredna Kretanjai Ekonomska Politika, 108, 67-86.

Anselmsson, T., Tohansson, U., \& Persson, N. (2007). Understanding Price Premium for Grocery Products: A Conceptual Model of Customer-Based Brand Equity. Journal of Product \& Brand Management, 16(6), 401-414. https://doi.org/10.1108/10610420710823762

Asamoah, E. S. (2014). Customer Based Brand Equity (CBBE) and the Competitive Performance of SMEs in Ghana. Journal of Small Business and Enterprise Development, 21(1), 117-131. https://doi.org/10.1108/JSBED-10-2013-0154 
Ashill, N., \& Sinha, A. (2004). An Exploratory Study into the Impact of Components of Brand Equity and Country of Origin Effects on Purchase Intention. Journal of Asia-Pacific Business, 5(3), 27-43. https://doi.org/10.1300/J098v05n03_03

Atilgan, E., Aksoy, S., \& Akinci, S. (2005). Determinants of Brand Equity: A Verification Approach in the Beverage Industry in Turkey. Marketing Intelligence \& Planning, 23(3), 237-248. https://doi.org/10.1108/02634500510597283

Bagozzi, R. P. (1994). The Effects of Arousal on the Organization of Positive and Negative Affect and Cognitions: Application to Attitude Theory. Structural Equation Modeling, 1(3), 222-252. https://doi.org/10.1080/10705519409539976

Bagozzi, R. P., \& Yi, Y. (1988). On the Evaluation of Structural Equation Models. Journal of the Academy of Marketing Science, 16 (1), 74-94. https://doi.org/10.1007/BF02723327

Baldauf, A., Gravens, K. S., \& Binder, G. (2003). Performance Consequences of Brand Equity Management: Evidence from Organizations in the Value Chain. Journal of Product and Brand Management, 12(4), 220-236. https://doi.org/10.1108/10610420310485032

Bauer, H. H., Stockburger-Sauer, N. E., \& Exler, S. (2008). Brand Image and Fan Loyalty in Professional Team Sport: A Refined Model and Empirical Assessment. Journal of Sport Management, 2(2), 205-226. https://doi.org/10.1123/jsm.22.2.205

Bendixen, M., Bukasa, K. A., \& Abratt, R. (2004). Brand Equity in the Business-to-Business Market. Industrial Marketing Management, 33(5), 371-380. https://doi.org/10.1016/j.indmarman.2003.10.001

Berry, L. (1995). Relationship Marketing of Services: Growing Interest, Emerging Perspectives. Journal of the Academy of Marketing Science, 23, 236-245. https://doi.org/10.1177/009207039502300402

Biedenbach, G. (2012). Brand Equity in the Business-to-Business Context: Examining the Structural Composition. Journal of Brand Management, 19(8), 688-701. https://doi.org/10.1057/bm.2011.60

Bitner, M. J. (1992). Service Capes: The Impact of Physical Surroundings on Customers and Employees. Journal of Marketing, 56, 57-71. https://doi.org/10.1177/002224299205600205

Blankston, M. (1992). Observations: Building Brand Equity by Managing Brand's Relationship. Journal of Advertising Research, 32(3), 79-83.

Bloemer, J., Buyter, K., \& Wetzels, M. (1997). On the Relationship Between Perceived Service Quality, Service Loyalty and Switching Costs. International Journal of Service Industry Management, 9(5), 436-453. https://doi.org/10.1108/09564239810238848

Bolton, R. N., \& Drew, J. H. (1991). A Multi-stage Model of Customer's Assessment of Service Quality and Value. Journal of Consumer Research, 17(4), 365-384. https://doi.org/10.1086/208564

Bornmark, H., Goransson, A., \& Svensson, C. (2005). A Study to Indicate the Importance of Brand Awareness in Brand Choice. Dissertation, International Business Program, Kristainstad University.

Brakus, J. J., Schmitt, B. H., \& Zarantonello, L. (2009). Brand Experience: What is it? How is it measured? Does it affect loyalty? Journal of Marketing, 73(3), 52-68. https://doi.org/10.1509/jmkg.73.3.052

Bryne, B. M. (2010). Structural Equation Modeling with Amos: Concepts, Applications and Programming (2nd ed.). Routledge.

Burmann, C., Jost-Benz, M., \& Riley, N. (2009). Towards an Identity-Based Brand Equity Model. Journal of Business Research, 62(3), 390-397. https://doi.org/10.1016/j.jbusres.2008.06.009

Chang, E. (2014). Influence of Spokes-Character on Brand Equity Antecedents. Asia Pacific Journal of Marketing and Logistics, 26(3), 494-515. https://doi.org/10.1108/APJML-02-2013-0030

Chaudhuri, A., \& Holbrook, M. B. (2001). The Chain of Effects from Brand Trust and Brand Affect to Brand Performance: The Role of Brand Loyalty. Journal of Marketing, 65(2), 81-93. https://doi.org/10.1509/jmkg.65.2.81.18255

Chen, C. (2001). Using Free Associations to Examine the Relationship Between the Characteristics of Brand Associations and Brand Equity. The Journal of Product and Brand Management, 10(6/7), 439-451. https://doi.org/10.1108/10610420110410559

Chiou, J. S., \& Droge, C. (2006). Service Quality, Trust, Specific Asset Investment and Expertise: Direct and Indirect Effects in a Satisfaction-Loyalty Framework. Journal of the Academy of Marketing Science, 34(4), 
613-627. https://doi.org/10.1177/0092070306286934

Cho, J. E., \& Hu, H. (2009). The Effect of Service Quality on Trust and Commitment Varying Across Generations. International Journal of Consumer Studies, 33(4), 468-476. https://doi.org/10.1111/j.1470-6431.2009.00777.x

Cobb-Walgren, C. J., Beal, C., \& Donthu, N. (1995). Brand Equity, Brand Preferences and Purchase Intent. Journal of Advertising, 24(3), 25-40. https://doi.org/10.1080/00913367.1995.10673481

Daggar, T. S., Sweeney, J. C., \& Johnson, L. W. (2007). A Hierarchical Model of Health Service Quality: Scale Development and Investigation of an Integrated Model. Journal of Service Research, 10(2), 123-142. https://doi.org/10.1177/1094670507309594

Das, G. (2016). Antecedents and Consequences of Trust: An E-Tail Branding Perspective. International Journal of Retail \& Distribution Management, 44(7), 713-730. https://doi.org/10.1108/IJRDM-06-2015-0089

Dib, H., \& Alhaddad, A. (2104). The Hierarchical Relationship Between Brand Equity Dimensions. European Scientific Journal, 10(28), 183-194.

Dick, A. S., \& Basu, K. (1994). Customer Loyalty: Toward an Integrated Conceptual Framework. Journal of the Academy of Marketing Science, 22, 99-113. https://doi.org/10.1177/0092070394222001

Doney, P. M., \& Cannon, J. P. (1997). An Examination of the Nature of Trust in Buyer-Seller Relationships. Journal of Marketing, 61(2), 35-51. https://doi.org/10.1177/002224299706100203

Doyle, P. (2001). Shareholder-Value-Based Brand Strategies. Journal of Brand Management, 9(1), 20-30. https://doi.org/10.1057/palgrave.bm.2540049

East, R., Harris, P., William, G., \& Lomax, W. (1995). Loyalty to Supermarkets. International Review of Retail, Distribution \& Consumer Research, 5(1), 99-109. https://doi.org/10.1080/09593969500000006

Emari, H., Jafari, A., \& Mogaddam, M. (2012). The Mediatory Impact of Brand Loyalty and Brand Image on Brand Equity. African Journal of Business Management, 6(17), 5692-5701. https://doi.org/10.5897/AJBM11.788

Farquhar, P. H., Han, J. Y., \& Ijiri, Y. (1991). Recognizing and Measuring Brand Assets (Report No. 91-119). Working Paper Series, Marketing Science Institute, Cambridge, MA.

Fornell, C., \& Larcker, D. F. (1981). Evaluating Structural Equation Models with Unobservable Variables and Measurement Error. Journal of Marketing Research, 18(1), 39-80. https://doi.org/10.2307/3151312

Gefen, D. (2000). E-Commerce: The Role of Familiarity and Trust. Omega, 28(6), 725-737. https://doi.org/10.1016/S0305-0483(00)00021-9

Gounaris, S. P. (2005). Trust and Commitment Influences on Customer Retention: Insights from Business-To Business Services. Journal of Business Research, 58, 126-140. https://doi.org/10.1016/S0148-2963(03)00122-X

Gronroos, C. (1984). A Service Quality Model and Its Marketing Implications. European Journal of Marketing, 18(4), 36-44. https://doi.org/10.1108/EUM0000000004784

Hai, C., \& Seetharaman, P. B. (2009). Speed of Replacement: Modeling Brand Loyalty Using Last-Move Data. Journal of Marketing Research, 46(4), 494-505. https://doi.org/10.1509/jmkr.46.4.494

Hamann, D., William, R. L. Jr., \& Omar, M. (2007). Branding Strategy and Consumer High-Technology Product. Journal of Product and Brand Management, 16(2), 98-111. https://doi.org/10.1108/10610420710739973

Harris, L. C., \& Goode, M. M. H. (2004). The Four Levels of Loyalty and the Pivotal Role of Trust: A Study of Online Service Dynamics. Journal of Retailing, 80, 139-158. https://doi.org/10.1016/j.jretai.2004.04.002

Hoffman, D. L., Novak, T. P., \& Peralta, M. (1999). Building Consumer Trust on Online. Communications of the ACM, 42(4), 80-85. https://doi.org/10.1145/299157.299175

Hoyer, W. D., \& Brown, S. P. (1990). Effects of Brand Awareness on Choice for a common Repeat-Purchase Product. Journal of Consumer Research, 17(2), 141-148. https://doi.org/10.1086/208544

Izogo, E. E., Ogba, I., \& Nwekpa, K. C. (2016). Correlates of the Determinants of Relationship Marketing in the Retail Sector: The Nigerian Case. African Journal of Economic and Management Studies, 7(1), 30-53. https://doi.org/10.1108/AJEMS-04-2014-0023

Jones, M. A., Beatty, S. E., \& Mothersbaugh, D. V. (2002). Why Customers Stay: Measuring the Underlining 
Dimensions of Services Switching Costs and Managing the Differential Strategic Outcomes. Journal of Business Research, 55, 441-450. https://doi.org/10.1016/S0148-2963(00)00168-5

Joubert, J. P. R., \& Poalses, J. (2012). What's in A Name? The Effect of a Brand Name on Consumers' Evaluation of Fresh Milk. International Journal of Consumer Studies, 36, 425-431. https://doi.org/10.1111/j.1470-6431.2011.01065.x

Kaldou, S., \& Kehagias, J. (2014). Assessing Destination Brand Equity: An Integrated Approach. Journal of Destination Marketing \& Management, 3, 2-10. https://doi.org/10.1016/j.jdmm.2013.11.002

Kaynak, E., Salman, G. G., \& Tatoglu, E. (2008). An Integrative Framework Linking Brand Associations and Brand Loyalty in Professional Sports. Brand Management, 15(5), 336-357. https://doi.org/10.1057/palgrave.bm.2550117

Keller, K. L. (1993). Conceptualizing, Measuring and Managing Customer-Based Brand Equity. Journal of Marketing, 57(1), 1-22. https://doi.org/10.1177/002224299305700101

Keller, K. L. (2001). Building Customer-Based Brand Equity. Marketing Management, 10(2), 15-19.

Keller, K. L. (2002). Strategic Brand Management: Building, Measuring and Managing Brand Equity (2nd ed.). Pearson Education, Upper Saddle River, NJ.

Keller, K. L. (2003). Brand Synthesis: The Multidimensionality of Brand Knowledge. Journal of Consumer Research, 29, 595-601. https://doi.org/10.1086/346254

Keller, K. L. (2008). Strategic Brand Management: Building, Measuring and Managing Brand Equity (3rd ed.). Pearson Prentice Hall, Upper Saddle River, NJ.

Keller, K. L. (2009). Building Strong Brands in a Modern Marketing Communications Environment. Journal of Marketing Communications, 15(2/3), 139-155. https://doi.org/10.1080/13527260902757530

Keller, K. L., \& Lehmann, D. R. (2003). How Do Brands Create Value? Marketing Management, 12(3), 26-31.

Kim, S. S., Choe, J. Y. J., \& Petrick, J. F. (2018). The Effect of Celebrity on Brand Awareness, Perceived Quality, Brand Image, Brand Loyalty and Destination Attachment to a Literary Festival. Journal of Destination Marketing \& Management, 9, 320-329. https://doi.org/10.1016/j.jdmm.2018.03.006

Kotler, P. (1991). Marketing Management (7th ed.). Prentice-Hall, Upper Saddle River, NJ.

Kumar, R. S., Dash, S., \& Purwar, P. C. (2013). The Nature ad Antecedents o Brand Equity and Its Dimensions. Marketing Intelligence \& Planning, 31(2), 141-159. https://doi.org/10.1108/02634501311312044

Lassar, W., Mittal, B., \& Sharma, A. (1995). Measuring Customer Based Brand Equity. Journal of Consumer Marketing, 12(4), 11-19. https://doi.org/10.1108/07363769510095270

Lee, B. Y., \& Park, S. Y. (2019). The Role of Customer Delight and Customer Equity for Loyalty in Upscale Hotels. Journal of Hospitality and Tourism Management, 39, 175-184. https://doi.org/10.1016/j.jhtm.2019.04.003

Lien, C., Wu, J., Chen, Y., \& Wang, C. (2014). Trust Transfer and the Effects of Service Quality on Trust in the Healthcare Industry. Managing Service Quality, 24(4), 399-416. https://doi.org/10.1108/MSQ-11-2013-0255

Low, G., \& Lamb, C. Jr. (2000). The measurement and dimensionality of brand associations. Journal of Product \& Brand Management, 9(6), 350-370. https://doi.org/10.1108/10610420010356966

Mishra, S., \& Prasad, S. (2014). Exploring Linkages Between Socio-Demographic Factors and Customer loyalty in India. Management and Marketing, 9(1), 13-26.

Moisescu, O. I. (2009). The Influence of Market Type and Demographics on Brand Loyalty: A Study among Urban Romanian Consumers. Retrieved from http://SteconomiceUoradea.ro/anale/Volume/2009/V4-management and marketing/ 147.PDF

Moorman, C., Deshpande, R., \& Zaltman, G. (1993). Factors affecting Trust in Market Research Relationships. Journal of Marketing, 57, 81-101. https://doi.org/10.1177/002224299305700106

Morgan, R. M., \& Hunt, S. D. (1994). The Commitment-Trust Theory of Relationship Marketing. Journal of Marketing, 58, 20-38. https://doi.org/10.1177/002224299405800302

Mourad, M., Ennew, C., \& Kortam, W. (2010). Descriptive Evidence on the Role of Corporate Brands in Marketing Higher Education Services. Service Science, 2(3), 154-166. https://doi.org/10.1287/serv.2.3.154 
Nguyen, T. D., Baarett, N. J., \& Miller, K. E. (2011). Brand Loyalty in Emerging Markets. Marketing Intelligence \& Planning, 29(3), 222-232. https://doi.org/10.1108/02634501111129211

Oliver, R. L. (1999). Whence Consumer Loyalty. Journal of Marketing, 63, 33-44. https://doi.org/10.2307/1252099

Pappu, R., \& Quester, P. (2006). Does Customer Satisfaction Lead to Improved Brand Equity? An Empirical Examination of Two Categories of Retail Brands. Journal of Product and Brand Management, 15(1), 4-14. https://doi.org/10.1108/10610420610650837

Pappu, R., \& Quester, P. (2008). Does Brand Equity Vary Between Department Stores and Clothing Store? Results of an Empirical Investigation. Journal of Product and Brand Management, 1, 425-435. https://doi.org/10.1108/10610420810916335

Pappu, R., Quester, P., \& Cooksey, W. R. (2005). Consumer-Based Brand Equity: Improving the Measurement-Empirical Evidence. The Journal of Product and Brand Management, 14(2/3), 143-154. https://doi.org/10.1108/10610420510601012

Parasuraman, A., Zeithmal, V. A., \& Berry, L. L. (1985). A Conceptual-Model of Service Quality and Its Implications for Future-Research. Journal of Marketing, 49, 41-50. https://doi.org/10.1177/002224298504900403

Patterson, P. G. (2007). Demographic Correlates of Loyalty in a Service Context. Journal of Services Marketing, 21(2), 112-121. https://doi.org/10.1108/08876040710737877

Peterson, R. A. (1995). Relationship Marketing and the Consumer. Journal of the Academy of Marketing Science, 23(4), 278-281. https://doi.org/10.1177/009207039502300407

Pike, S., Bianchi, C., Kerr, G., \& Patti, C. (2010). Consumer-Based Brand Equity for Australia as a Long-haul Tourism Destination in an Emerging Market. International Marketing Review, 27(4), 434-449. https://doi.org/10.1108/02651331011058590

Qu, H., Kim, H., \& Im, H. (2011). A Model of Destination Branding: Integrating the Concepts of Branding and Destination Image. Tourism Management, 32(3), 465-476. https://doi.org/10.1016/j.tourman.2010.03.014

Raut, U. R. (2015). A Study on Brand Loyalty and Its Associations with Demographics of Consumers: Evidence from the Cell phone Market of India. The IUP Journal of Brand Management, 12(3), 30-45.

Rios, R. E., \& Riquelme, H. E. (2008). Brand Equity for Online Companies. Marketing Intelligence \& Planning, 26(7), 719-742. https://doi.org/10.1108/02634500810916681

Rossiter, J. R., \& Percy, L. (1987). Advertising and Promotion Management. New York City, NY: Mc Graw-Hill Book Company.

Roy, D. G., Mukherjee, S., \& Bhattacharya, S. (2018). Empirical Research on CBBE Scale for Medical Tourism. International Journal of Pharmaceutical and Healthcare Marketing, 12(3), 348-370. https://doi.org/10.1108/IJPHM-12-2017-0074

Rust, R. T., \& Oliver, R. L. (1994). Service Quality: Insights and Managerial Implications from the Frontier. In R. T. Rust \& R. L. Oliver (Eds.), Service Quality: New Directions in Theory and Practice (pp. 1-19). Thousand Oaks, CA: Sage Publications. https://doi.org/10.4135/9781452229102.n1

Saad, R., Ishak. H., \& Johari, N. R. (2013). The Impact of Demographic Factors toward Consumer Loyalty: A Study on Credit Card Users. Elixir Marketing Management, 55, 13078-13084.

Shoell, W. F., \& Guiltinan, J. P. (1990). Marketing Contemporary Concepts and Practices. Boston, MA: Allyn $\&$ Bacon.

Simon, C. J., \& Sullivan, M. W. (1993). The measurement and determinants of brand equity: A financial approach. Marketing Science, 12(1), 28-52. https://doi.org/10.1287/mksc.12.1.28

Sirdeshmukh, D., Singh, J., \& Sabol, B. (2002). Consumer Trust, Value and Loyalty in Relational Exchanges. Journal of Marketing, 66, 15-37. https://doi.org/10.1509/jmkg.66.1.15.18449

Stojanovic, I., Andreu, L., \& Curras-Perez, R. (2018). Effects of the Intensity of Use of Social Media on Brand Equity: An Empirical Study in a Tourist Destination. European Journal of Management and Business Economics, 27(1), 83-100. https://doi.org/10.1108/EJMBE-11-2017-0049

Su, J., \& Chang, A. (2018). Factors Affecting College Students' Brand Loyalty Toward Fast Fashion. Journal of Retail \& Distribution Management, 46(1), 90-107. https://doi.org/10.1108/IJRDM-01-2016-0015 
Tong, X., \& Hawley, J. M. (2009). Measuring Customer-Based Brand Equity: Empirical Evidence from Sport Wear Market in China. Journal of Product and Brand Management, 18(4), 262-271. https://doi.org/10.1108/10610420910972783

Urde, M. (1994). Brand Orientation-A Strategy for Survival. Journal of Consumer Marketing, 11(3), 18-32. https://doi.org/10.1108/07363769410065445

Van Riel, A. C. R., De Mortanges, C. P., \& Streukens, S. (2005). Marketing Antecedents of Industrial Brand Equity: An Empirical Investigation in Specialty Chemicals. Industrial Marketing Management, 34(8), 841-847. https://doi.org/10.1016/j.indmarman.2005.01.006

Washburn, J., \& Plank, R. (2002). Measuring Brand Equity: An Evaluation of a Consumer-Based Brand Equity Scale. Journal of Marketing Theory and Practice, 10(1), 46-62. https://doi.org/10.1080/10696679.2002.11501909

Wood, L. M. (2004). Dimensions of Brand Purchasing Behavior: Consumers in the 18-24 Age Group. Journal of Consumer Behavior, 4(1), 9-24. https://doi.org/10.1002/cb.154

Wu, J. J., Chen, Y. H., \& Chung, Y. S. (2010). Trust Factors Influencing Virtual Community members: A Study of Transaction Communities. Journal of Business Research, 63(9), 1025-1032. https://doi.org/10.1016/j.jbusres.2009.03.022

Wu, J., \& Tian, Z. (2009). The Impact of Selected Store Image Dimensions on Retailer Equity: Evidence from 10 Chinese Hypermarkets. Journal of Retailing and Consumer Services, 16(6), 486-494. https://doi.org/10.1016/j.jretconser.2009.08.002

Xu, J. B., \& Chan, A. (2010). A Conceptual Framework of Hotel Experience and Customer-Based Equity: Some Research Questions and Implications. International Journal of Contemporary Hospitality Management, 22(2), 174-193. https://doi.org/10.1108/09596111011018179

Yang, Z., \& Peterson, R. (2004). Customer Perceived Value, Satisfaction and Loyalty: The Role of Switching Costs. Psychology \& Marketing, 21(10), 799-822. https://doi.org/10.1002/mar.20030

Yoo, B., Donthu, N., \& Lee, S. (2000). An Examination of Selected Marketing Mix Elements and Brand Equity. Journal of the Academy of Marketing Science, 28(2), 195-211. https://doi.org/10.1177/0092070300282002

Yoon, S. J. (2002). The antecedents and Consequences of Trust in Online-Purchase Decisions. Journal of Interactive Marketing, 16(2), 47-63. https://doi.org/10.1002/dir.10008

Zeithmal, V. A. (1988). Consumer Perceptions of Price, Quality and Value: A Means-End Model and Synthesis of Evidence. Journal of Marketing, 52(3), 2-22. https://doi.org/10.1177/002224298805200302

Zhang, S., Doorn, J. V., \& Leeflang, P. S. H. (2014). Does the Importance of Value, Brand and Relationship Equity for Customer Loyalty Differ Between Eastern and Western Cultures? International Business Review, 23, 284-292. https://doi.org/10.1016/j.ibusrev.2013.05.002 


\section{Appendix A}

\begin{tabular}{|c|c|c|}
\hline Construct & Measurement Items & Source \\
\hline Brand Awareness & $\begin{array}{l}\text { - I am aware of mobile service company which I deal with. } \\
\text { - I can recognize the symbol or logo of mobile service company which I deal with. } \\
\text { - I can recognize the mobile service company which I deal with among competing } \\
\text { companies. }\end{array}$ & (Yoo, et al., 2000) \\
\hline Brand Association & $\begin{array}{l}\text { - I like and admire the mobile service company which a deal with. } \\
\text { - Some positive characteristics of mobile service company which I deal with come to my } \\
\text { mind quickly. }\end{array}$ & (Yoo, et al., 2000) \\
\hline Brand Association & $\begin{array}{l}\text { - The mobile service company which I deal with has unique image in my mind as compared } \\
\text { to other competing companies. }\end{array}$ & $\begin{array}{l}\text { (Tong and Hawley, } \\
\text { 2009) }\end{array}$ \\
\hline Brand Association & - It's difficult to forget mobile service company which I deal with. & (Aaker, 1996b) \\
\hline Perceived & - Mobile Service Company's staff takes care of services in promised time. & (Aaker, 1996a) \\
\hline Brand & - Mobile Service Company has courteous personnel. & \\
\hline Quality & $\begin{array}{l}\text { - Mobile Service Company's staff corrects mistakes quickly. } \\
\text { - Mobile Service Company has experienced personnel. } \\
\text { - Mobile service company's personnel are knowledgeable about all areas of company } \\
\text { services. } \\
\text { - Mobile service company's personnel take care of tasks accurately. }\end{array}$ & \\
\hline Perceived & - I believe that mobile service company which I deal with offers superior service in every & (Dagger, et al., 2007) \\
\hline Brand & way. & \\
\hline Quality & $\begin{array}{l}\text { - The overall quality of service provided by mobile service company which I deal with is } \\
\text { excellent. } \\
\text { - The quality of service provided at mobile service company which I deal with is } \\
\text { impressive. } \\
\text { - The service provided by mobile service company which I deal with is high standard. }\end{array}$ & \\
\hline Brand Trust & $\begin{array}{l}\text { - Mobile Service Company which I deal with is trustworthy. } \\
\text { - I believe in the information provided by the mobile service company which I deal with. } \\
\text { - The mobile service company which I deal with keeps the promises provided to its } \\
\text { customers. } \\
\text { - The mobile service company which I deal with is honest and sincere in addressing my } \\
\text { concerns. } \\
\text { - The mobile service company which I deal with is genuinely concerned about my } \\
\text { wellbeing. }\end{array}$ & $\begin{array}{l}\text { (Doney and Cannon, } \\
\text { 1997) }\end{array}$ \\
\hline Brand Loyalty & $\begin{array}{l}\text { - I consider myself to be loyal to mobile service company which I deal with. } \\
\text { - When buying mobile service, the mobile service company which I deal with is my first } \\
\text { choice. } \\
\text { - I would not deal with other mobile service companies if mobile service company which I } \\
\text { deal with is available. } \\
\text { - Even if another mobile service company has the same facilities as mobile service } \\
\text { company which I deal with, I would prefer mobile service company which I deal with. } \\
\text { - If another mobile service company is not different from mobile service company which I } \\
\text { deal with, it seems smarter to choose mobile service company which I deal with. } \\
\text { - It makes sense to choose mobile service company which I deal with instead of any other } \\
\text { mobile service companies even they are the same. } \\
\text { - I will keep deal with mobile service company which I deal with as it provides satisfied } \\
\text { service. } \\
\text { - I am still willing to buy service from mobile service company which I deal with even if its } \\
\text { prices are little higher than that of its competitors. }\end{array}$ & (Yoo, et al., 2000) \\
\hline
\end{tabular}

\section{Copyrights}

Copyright for this article is retained by the author, with first publication rights granted to the journal.

This is an open-access article distributed under the terms and conditions of the Creative Commons Attribution license (http://creativecommons.org/licenses/by/4.0/). 